\title{
A partial life cycle assessment approach to evaluate the energy intensity and related greenhouse gas emission in dairy farms
}

\author{
Lelia Murgia, Giuseppe Todde, Maria Caria, Antonio Pazzona \\ University of Sassari, Department of Agraria, Sassari, Italy
}

\begin{abstract}
Dairy farming is constantly evolving towards more intensive levels of mechanization and automation which demand more energy consumption and result in higher economic and environmental costs. The usage of fossil energy in agricultural processes contributes to climate change both with on-farm emissions from the combustion of fuels, and by off-farm emissions due to the use of grid power. As a consequence, a more efficient use of fossil resources together with an increased use of renewable energies can play a key role for the development of more sustainable production systems. The aims of this study were to evaluate the energy requirements (fuels and electricity) in dairy farms, define the distribution of the energy demands among the different farm operations, identify the critical point of the process and estimate the amount of $\mathrm{CO}_{2}$ associated with the energy consumption. The inventory of the energy uses has been outlined by a partial Life Cycle Assessment (LCA) approach, setting the system boundaries at the farm level, from cradle to farm gate. All the flows of materials and energy associated to milk production process, including crops cultivation for fodder production, were investigated in 20 dairy commercial farms over a period of one year. Self-produced energy from renewable sources was also accounted as it influence the overall balance of emissions. Data analysis was focused on the calculation of energy and environmental sustainability indicators (EUI, $\mathrm{CO}_{2}-\mathrm{eq}$ ) referred to the functional units. The production of $1 \mathrm{~kg}$ of Fat and Protein Corrected Milk (FPCM) required on average $0.044 \mathrm{kWh}_{\mathrm{el}}$ and $0.251 \mathrm{kWh}_{\text {th }}$, corresponding to a total emission of $0.085 \mathrm{~kg} \mathrm{CO}_{2}$-eq). The farm activities that contribute most to the electricity requirements were milk cooling, milking and slurry management, while feeding management and crop cultivation were the greatest diesel fuel consuming operation and the largest in terms of environmental impact of milk production (73\% of energy $\mathrm{CO}_{2}$-eq emissions). The results of the study can assist in the development of dairy farming models based on a more efficient and profitable use of the energy resources.
\end{abstract}

\footnotetext{
Correspondence: Lelia Murgia, University of Sassari, Department of Agraria viale Italia 39, 07100 Sassari, Italy.

E-mail: dit_mecc@uniss.it

Key words: elecricity, fuel, carbon footprint, LCA.

(C) Copyright L. Murgia et al., 2013

Licensee PAGEPress, Italy

Journal of Agricultural Engineering 2013; XLIV(s2):e37

doi:10.4081/jae.2013.s2.e37

This article is distributed under the terms of the Creative Commons Attribution Noncommercial License (by-nc 3.0) which permits any noncommercial use, distribution, and reproduction in any medium, provided the original author(s) and source are credited.
}

\section{Introduction}

Energy consumption, water utilization and environmental impact are becoming the major issues in the agro-food sector that is called to respond adequately to the climate change problems. Agricultural and livestock activities are important sources of primary greenhouse gases (GHGs). These sectors have been estimate to contribute for about 10$12 \%$ to global anthropogenic GHG emissions (Grosson et al., 2011; Smith et al., 2007). Furthermore, agriculture is responsible of indirect emissions in other industrial sectors which supply the resources consumed in the agricultural processes (IPCC 2006). The usage of fossil energy in agricultural processes contributes to climate change both with on-farm emissions from the combustion of fuels, and by off-farm emissions due to production and transport to the farm of agricultural inputs (West et al., 2010). As a consequence, a more efficient use of fossil resources together with an increased use of renewable energies can play a key role for the development of more sustainable production systems.

The methodology that is internationally applied to assess the global impact associated to production activities or products is Life Cycle Assessment (LCA). LCA allows to analyse all the inputs and outputs of a system to estimate the potential environmental impact of a product or service through its life cycle (UNI EN ISO 14040-44 2006). The stages of LCA are: goal and scope definition, inventory analysis, impact assessment an interpretation of results. The system boundaries are used to define the limit of the study and results of LCA are expressed for functional unit of product. All data concerning the use of resources, the energy requirements, the emissions and the products resulting from each process are collected during the inventory analysis. As the impact categories and the level of detail of the analysis can be chosen and specified, the LCA procedure can be tailored to the goals of the study.

The aims of this study were to evaluate the energy requirements in dairy farms, define the distribution of the energy demands among the different farm operations, identify the critical point of the process and estimate the amount of $\mathrm{CO}_{2}$ associated with the energy consumption. The study, based on a simplified LCA approach, involved 20 dairy conventional farms over a period of one year, half of which have a photovoltaic system for electricity generation.

\section{Materials and methods}

This work is a part of a larger research project (Dairy Carbon Footprint-Filiera $A Q$ ) involving 285 dairy farms located in the centre and south Italy and which aims to assess the potential environmental impact of milk production at farm level. A sample of 20 dairy farms, located in the Arborea area (Sardinia, Italy) are analysed in this study to quantify the fossil energy flows and the carbon dioxide equivalent $\left(\mathrm{CO}_{2}\right.$-eq) emissions associated to farming activities. 
Data inventoried in each farm, related to year 2011, include general information such as herd size, animal categories, land used, milk quality and production, and a detailed description of cultivated crops, farm structures, equipment and machinery.

Detailed statistics of the monthly energy flows, such as consumption bills of fuels and electricity and the self-produced energy from photovoltaic (PV) generators, were recorded.

The overall data were structured in a data base created on Microsoft Excel. Further calculations were performed to determine sustainability indicators, such as Energy Utilization Indices (EUI) and $\mathrm{CO}_{2}$-eq emissions referred to functional units (cows, $\mathrm{kg}$ of Fat and Protein Corrected Milk -FPCM), that can be compared to literature data.

A detailed energy auditing was performed to allocate the energy consumptions among the different farm activities. All the electrical appliances operating at farm level have been inventoried, reporting the power of each equipment and its usage time (hours per day, days per year) to obtain the annual electricity consumption. Additionally, comparison between the audit data and the electricity bills were performed to evaluate the conformity of the results.

The following farm activities have been detailed:

Lighting: type and power of lamps, as well the illumination time, were collected from barns and farm's facilities

Ventilation and misting: used to lower the air temperature in cowsheds and reduce cow's heat stress during the warm season. These equipment run only when the temperature is above $20-25^{\circ} \mathrm{C}$, and the usage time was obtained from the manager interview.

Brushing: $65 \%$ of the farm's sample uses mechanized brush to increase cow's comfort. The system is equipped with an electric motor that allows brush rotation as soon as the cow touches it. Operating time of cow brushing was set at 6 minutes/day per milking cow (DeVries, 2007).

Milking: the inputs due to the use of vacuum pump, milk pump and air compressor have been summed together to outline the total consumption of the milking operation. Additionally, the presence of a Variable Drive Speed (VDS) system was taken into account when assessing the electrical consumption of the vacuum pump. The VDS device allows reducing the speed of the vacuum pump based on the vacuum level requirement during milking, thus diminishing of $40-50 \%$ the electrical consumption. The $60 \%$ of the investigated farms were provided of a VDS system. Electrical consumptions of milk pump and air compressor were set as a $4 \%$ of the vacuum pump consumption.

Milk Cooling: electrical consumption for milk refrigeration shows high variations due to the presence or not of the pre-cooling system. The following procedure was used to assess the annual energy consumption $\left(R E_{e l}\right)$ of the milk tank:

$$
R E_{e l}=\frac{m \times c_{p} \times\left(t_{1}-t_{2}\right)}{C O P \times \eta \times 3.6} \quad\left[\mathrm{kWh} \cdot \mathrm{y}^{-1}\right]
$$

where $m(\mathrm{~kg} \cdot$ year-1 $)$ is the mass of milk, $c_{p}\left(\mathrm{MJ} \mathrm{kg}^{-1}{ }^{\circ} \mathrm{C}^{-1}\right)$ the milk specific heat value, $t_{1}$ and $t_{2}\left({ }^{\circ} \mathrm{C}\right)$ the initial and final milk temperatures, $C O P$ and $\eta$ are respectively the coefficient of performance and the efficiency of the refrigeration system, 3.6 the conversion factor from MJ to $\mathrm{kWh}$. The electricity required milk cooling is reduced by the use of precoolers which lower the temperature of the milk entering the tank. The magnitude of this reduction depends on the temperature of the cooling media; a decrease of $16^{\circ} \mathrm{C}$ was set in $t_{1}$ value when the pre-cooler was available ( $30 \%$ of the farms).

Water heating: both the milking system and the cooling tank need high volumes of water in order to clean and disinfect all the equipment used during the milking operation. Hot wash water $\left(50 \div 65^{\circ} \mathrm{C}\right)$ was used in 19 farms over 20 , while only one used warm water $\left(40^{\circ} \mathrm{C}\right)$. Different water heating systems were found during the survey: $85 \%$ of the investigated farms were equipped with an electrical water heater and $90 \%$ with heat recovery systems (HRS) which recuperate the heat given off by the condenser of the refrigeration circuit. The quantities of hot water produced vary based on the quantity of milk refrigerated.

The following equation was used to assess the energy () related with hot water consumptions:

$$
R E_{e l}=\frac{m \times c_{p} \times\left(t_{1}-t_{2}\right)}{C O P \times \eta \times 3.6} \quad\left[\mathrm{kWh} \cdot \mathrm{y}^{-1}\right]
$$

where $m\left(\mathrm{~kg} \cdot\right.$ year $\left.^{-1}\right)$ is the mass of wash water set at $12 \mathrm{~kg}$ per milking unit per milking (SCE, 2004) plus 150-200 L per day for the bulk tank, $c p\left(\mathrm{MJ} \mathrm{kg}^{-1}{ }^{\circ} \mathrm{C}^{-1}\right)$ the water specific heat value, $\mathrm{t}_{1}$ and $\mathrm{t}_{2}\left({ }^{\circ} \mathrm{C}\right)$ the initial and final water temperatures, $\eta$ the efficiency of the electric boiler, 3.6 the conversion factor from MJ to $\mathrm{kWh}$. Different $\Delta \mathrm{t}$ values were applied according to the presence/absence of HRS and the final water temperature required.

Water supply: energy consumptions have been split among water pumping, related only to cowshed and parlour water requirements, and irrigation, associated with the water distribution systems. All farms use an irrigation system of cultivated fields, but only $10 \%$ of them use water pumping.

Slurry management: energy consumptions are related to all the equipment used for manure removal, storage, and treatment.

Other: this section includes the operations with lower impact on dairy farm energy demands such as water treatment, feed preparation and high pressure cleaning.

Farm fuel consumptions have been grouped in three main processes: Field operations, related to forage and animal feed production. The overall tasks carried out for crop cultivation were divided into four sections: slurry distribution; soil tillage; sowing; fertilization and treatment; harvesting and storage of the product.

Slurry management, including operations as sewage management and treatment.

Feeding operations, regarding feed preparation and distribution by means of mixer trailers.

To estimate the tractor diesel consumption due to each operation, the usage time of the machinery, the power of the tractor and the fuel consumption at partial load $(Q)$ have been considered. $Q$ was derived from the following equation (Grisso et al., 2004): $Q=(0.22 X+0.096)$ $P_{p t o}\left(\mathrm{~L}^{\mathrm{h}} \mathrm{h}^{-1}\right)$ which considers the rated power of the machinery $\left(P_{p t o}\right.$, $k W$ ) and the estimated ratio (X, decimal) of the rated power being used during field operations. A value of 0.30 was set for light operations till to a value of 0.65 for the heaviest ones. A conversion factor of 0.835 $\mathrm{kg} \cdot \mathrm{L}^{-1}$ was then used to transform the equation results in $\mathrm{kg}$ of diesel.

The carbon dioxide emission derived from energy uses was calculated multiplying the total consumptions to the following specific emission factors: $0.4103 \mathrm{~kg} \mathrm{CO}_{2}$-eq $\mathrm{kWh}^{-1}$ (ISPRA 2011), based on the energy mix used to produce electricity in Italy, and $3.15 \mathrm{~kg} \mathrm{CO}_{2}$-eq kg-1${ }^{-1}$ ENEA 2010) to assess the emission from diesel combustion.

On farm renewable energy production was monitored in 10 farms which produce photovoltaic electricity. The total production of each PV system ( $\left.\mathrm{kWh} \cdot \mathrm{year}^{-1}\right)$ was analysed to determine the efficiency ( $\mathrm{kWh}$ per $\mathrm{kW}_{\mathrm{p}}^{-1}$ ) and to assess the reduction of carbon dioxide release into the environment. Per each $\mathrm{kWh}$ produced, a net emission factor of -0.3813 $\mathrm{kg} \mathrm{CO}$-eq was considered, derived from the difference between the index of the Italian energy mix $\left(0.4103 \mathrm{~kg} \mathrm{CO}_{2}\right.$-eq $\cdot \mathrm{kWh}^{-1}$, ISPRA 2011) and the $\mathrm{CO}_{2}$ emitted during the photovoltaic system production $(0.029$ $\mathrm{kg} \mathrm{CO}_{2}$-eq $\cdot \mathrm{kWh}^{-1}$, Raugei ethh al., 2009). 


\section{Results}

The characteristics of the studied farms and the annual energy consumptions are summarized in Table 1. The average herd dimension was 320 heads (range 158-500), of which about $44 \%$ are milking cows with an average yearly milk production of $10.1 \mathrm{t}$ per cow. The annual energy requirement accounted for $29,519 \mathrm{~kg}$ of diesel fuel and 55,843 $\mathrm{kWh}$ of electricity, which approximately correspond to an expenditure of $38,500 €$ per year.

Expressing the farm energy demand in terms of primary energy, which allows to compare the prevalence of the different energy resources, the diesel fuel accounts for about $70 \%$ of the total direct energy consumption at farm level, while the electricity represents the $30 \%$.

The farm average emission of carbon dioxide, due to all energy usages, was $120 \mathrm{t} \mathrm{CO}_{2}$-eq per year that corresponds to $0.085 \mathrm{~kg} \mathrm{CO}_{2}$-eq per kg of FPCM. Preliminary results on GHG production from the dairy farms included in the larger study indicate a prevalence of about $9 \%$ of the emissions due to fossil energy among the total GHG emissions.

The energy intensity of dairy farms represents the measure of energy efficiency and it is calculated as index of energy used (EUI) per unit of herd size or milk production. For the electricity, the $\mathrm{EUI}_{\mathrm{s}}$ resulted $401 \mathrm{kWh}$ per milking cow and $0.044 \mathrm{kWh} / \mathrm{kg}$ per FPCM per year. These results are lower than those found in similar studies carried out on European dairy farms. In a French study conducted by L'Institut de l'Elevage (2009) which involved 60 dairy farms (milk yield $7.2 \mathrm{t}$ cow ${ }^{1}$.year ${ }^{-1}$ ) the EUI was $420 \mathrm{kWh} /$ lactating cow and $0.059 \mathrm{kWh} / \mathrm{kg}$ of milk per year. These values are $4.5 \%$ higher than the present study in terms of $\mathrm{kWh}$ for lactating cows and $25 \%$ higher if referred to the unit of milk. Greater values are reported in an Italian study carried out on 60 dairy farms (milk yield $8 \mathrm{t} \mathrm{cow}^{-1}$ year ${ }^{-1}$ ) in the Emilia Romagna region (Rossi, 2012): $510 \mathrm{kWh}$ per cow per year and $0.064 \mathrm{kWh}$ per kg of milk per year. A German study (Jäkel, 2003) carried out on 41 dairy farms shows an average EUI of $0.09 \mathrm{kWh}$ per $\mathrm{kg}$ of milk, a value that is more than double of the present result. The EUI per unit of milk mirrors the value of 0.05 $\mathrm{kWh}$ obtained in a previous study carried on in the same region (Murgia et al., 2008), while the index per cow was much larger (466 $\mathrm{kWh}$ per lactating cow). The differences in farm technological levels and in yield per cow affect the energy efficiency indicators. Large productions of milk allows reducing the consumption of electricity per unit of milk sold.

The carbon dioxide emissions associated with the electricity inputs were $176 \mathrm{~kg} \mathrm{CO}_{2}$-eq/cow per year and $0.019 \mathrm{~kg} \mathrm{CO}_{2}$-eq $/ \mathrm{kg}$ of FPCM per year.

The annual consumption of diesel was $92 \mathrm{~kg}$ per cow, which corresponds to $0.021 \mathrm{~kg}$ diesel per $\mathrm{kg}$ of FPCM. The annual emissions deriving from these inputs were $289 \mathrm{~kg} \mathrm{CO}_{2}$-eq per cow and $0.066 \mathrm{~kg} \mathrm{CO}_{2}$-eq per $\mathrm{kg}$ of FPCM milk per year. When referred to the cultivated land, these indexes were $396 \mathrm{~kg}$ of diesel.ha-1 and $1248 \mathrm{~kg} \mathrm{CO}_{2}$-eq $\mathrm{ha}^{-1}$ per year.

As shown in figure $1 \mathrm{~A}$, milk refrigeration and milking result the most demanding operations in all the dairy farms examined, requiring respectively $23 \%$ and $19 \%$ of the annual electricity consumption. Also, other processes that affect significantly the electricity requirements are: slurry management (12\%), water pumping (11\%), irrigation (10\%), fan-misting operations (9\%) and water heating (8\%).

Analysing the diesel fuel consumption associated to farm and field processes (Figure 1B), the feed preparation and distribution represent together the $51 \%$ of the total fuel utilization, the land operations related to crop production account for $42 \%$ and the sewage management for $7 \%$.

Crop selection of the investigated farms was based on: corn silage (Zea Mays L., 100\% of the farms, average cultivation $26 \pm 12 \mathrm{ha} / \mathrm{farm}$ ); grass forage (Lolium spp., 100\% of the farms, $25 \pm 13$ ha/farm); Alfalfa forage (Medicago Sativa L., $55 \%$ of the farms, $10 \pm 4$ ha/farm).

Figure 2 illustrates the total carbon dioxide emission (diesel plus electricity) attributed to each farm operations. Diesel consumption, being responsible of $79 \%$ of the total emission from energy usages, represents the most pollutants process of the farms. Feed management represent the $40 \%$ of the total carbon dioxide emissions, followed by land operations (33\%) and slurry management (6\%). The use of electricity accounts for $21 \%$ of the total carbon dioxide emissions.

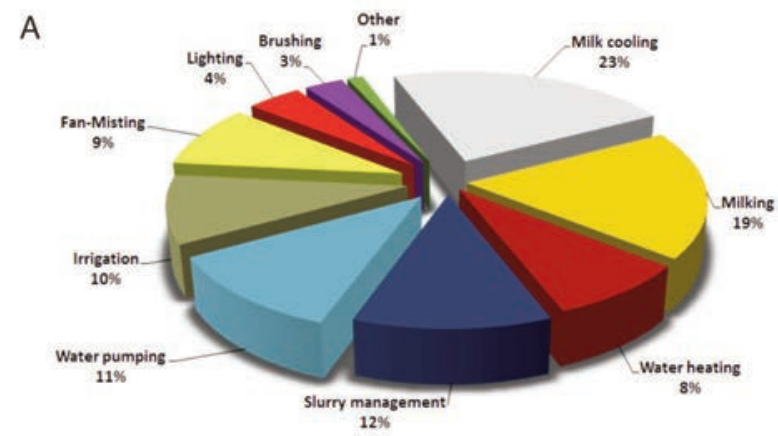

B

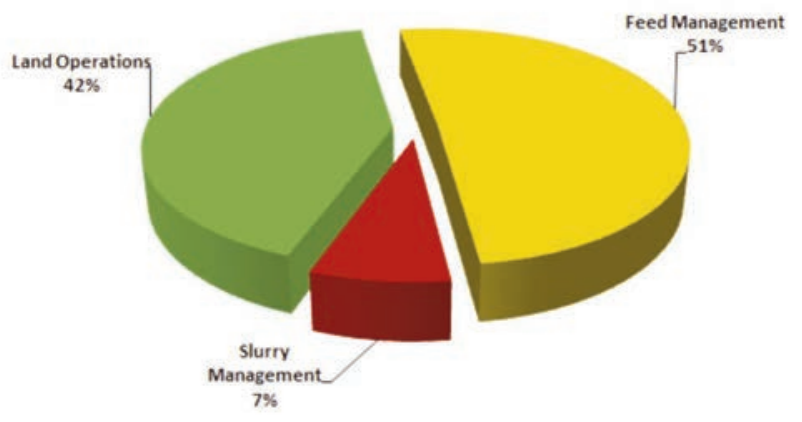

Figure 1. Allocation of fossil energy consumptions (A, electricity; B, diesel) among farm and field operation. Data from 20 dairy farms,

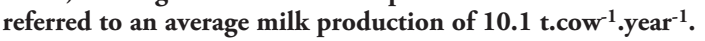

Table 1. Data summary of the examined farms $(\mathrm{N}=20)$

\begin{tabular}{|c|c|c|c|c|c|}
\hline & $\begin{array}{l}\text { Cows } \\
\text { (n) }\end{array}$ & $\begin{array}{l}\text { Land } \\
\text { (ha) }\end{array}$ & $\begin{array}{l}\text { Milk } \\
\left(\mathrm{t} \mathrm{y}^{-1}\right)\end{array}$ & $\begin{array}{c}\text { Diesel } \\
\left(\mathrm{kg} \mathrm{y}^{-1}\right)\end{array}$ & $\begin{array}{l}\text { Electricity } \\
\left(\mathrm{kWh} \mathrm{y}^{-1}\right)\end{array}$ \\
\hline Minimum & 158 & 14 & 822 & 12320 & 31343 \\
\hline Mean & 320 & 47 & 1412 & 29597 & 55843 \\
\hline Maximum & 500 & 95 & 2678 & 58394 & 163893 \\
\hline
\end{tabular}




\section{Photovoltaic energy analysis}

The production of energy by PV systems is able to fit the electricity trend demand in dairy farms, as shown in the example of figure 3 . The electricity consumption shows peak of request during the summer period due to the higher requests of energy for cooling the cowshed, milk refrigeration and irrigation. Photovoltaic generation follows the natural variability of solar radiation, with higher production during the summer period, peak value in July and minimum during winter months. Therefore PV energy generation can partially supply the demand of electricity during the lower peak of energy generation, but even exceed during the higher peak production. In this case, the surplus of electricity production is injected to the grid and sold.

The study has involved 10 farms which have installed a PV generator integrated on the roof top of the cowsheds. The total PV power installed accounts for 1,122 $\mathrm{kWp}$ (corresponding to $0.37 \mathrm{kWp}$ per cow), with an average value of $112 \mathrm{kWp}$ per farm (range $25-250 \mathrm{kWp}$ ). The analysis of the PV recorded productions indicates a specific production of about $1,387 \pm 14 \mathrm{kWh} / \mathrm{kWp}$ per year, which leads to a total electricity generation of $1,559,192 \mathrm{kWh}$ per year.

The PV electricity generation allows to decrease the high peak demand of grid energy during summer period, reducing the emission of carbon dioxide and the cost of the electricity purchased.

Results on yearly base show a positive balance in electricity net production. The surplus of electricity generation was sold, increasing the economic benefits of the farms and reducing the carbon footprint of the milk produced. Final analyses have shown on average a reduction of carbon dioxide emission of $0.023 \mathrm{~kg}$ of $\mathrm{CO}_{2}$-eq per $\mathrm{kg}$ of FPCM (from 0.085 to 0.062 ). The total carbon dioxide reduction was $29,726 \mathrm{~kg}$ of $\mathrm{CO}_{2}$-eq $\mathrm{y}^{1}$ which represents a $25 \%$ decrease of the total amount released by the whole group of farms.

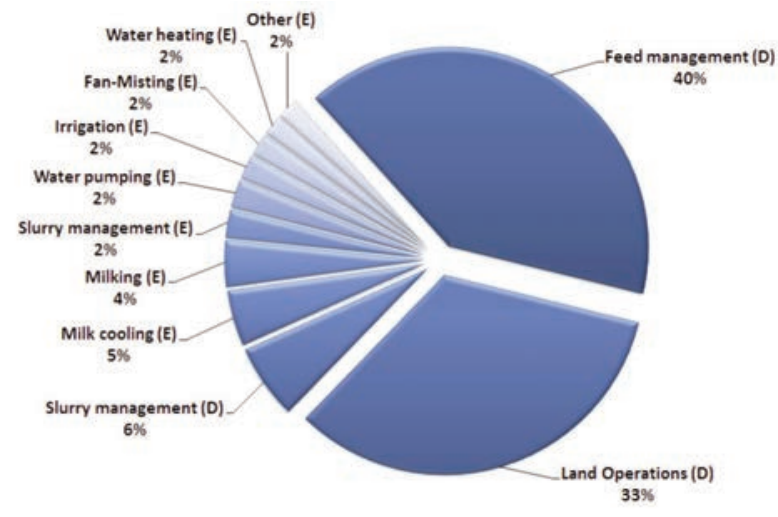

Figure 2. Allocation of GHG emissions from electricity (E) and Diesel (D) to different farm operations.

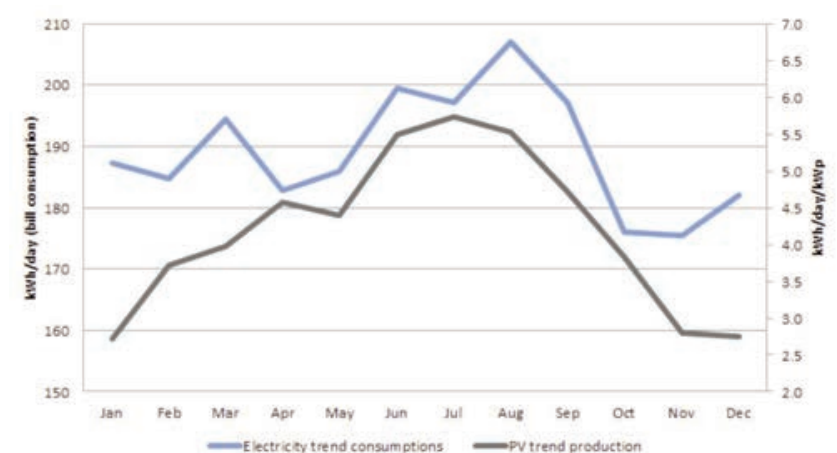

Figure 3. Monthly electricity consumptions and photovoltaic production

Table 2. Annual electricity and diesel consumptions (average \pm st.dev) and associated $\mathrm{CO}_{2}$-eq emissions.

\begin{tabular}{|c|c|c|c|c|c|c|}
\hline & & & & & Diesel & \\
\hline & $\begin{array}{c}\text { Consumption } \\
\text { (kWhel y-1) }\end{array}$ & $\begin{array}{c}\text { Emission } \\
\text { (kg CO2-eq) }\end{array}$ & Con & $\begin{array}{l}\text { mption } \\
\mathrm{y}-1)\end{array}$ & $\begin{array}{c}\text { Consumption } \\
\text { (kWhth) }\end{array}$ & $\begin{array}{c}\text { Emission } \\
\text { (kg C02-eq) }\end{array}$ \\
\hline Cow & $176 \quad( \pm 74)$ & 78 & 92 & $( \pm 21)$ & 1099 & 289 \\
\hline Lactating Cow & $401 \quad( \pm 180)$ & 176 & 209 & $( \pm 47)$ & 2496 & 658 \\
\hline Land (ha) & $768 \quad( \pm 358)$ & 338 & 396 & $( \pm 123)$ & 4730 & 1248 \\
\hline FPCM Milk (kg) & $0.044 \quad( \pm 0.03)$ & 0.019 & 0.02 & $\pm 0.005)$ & 0.251 & 0.066 \\
\hline
\end{tabular}

Table 3. Summary of the electricity comparison between farms with PV and without PV system; the results are expressed per year

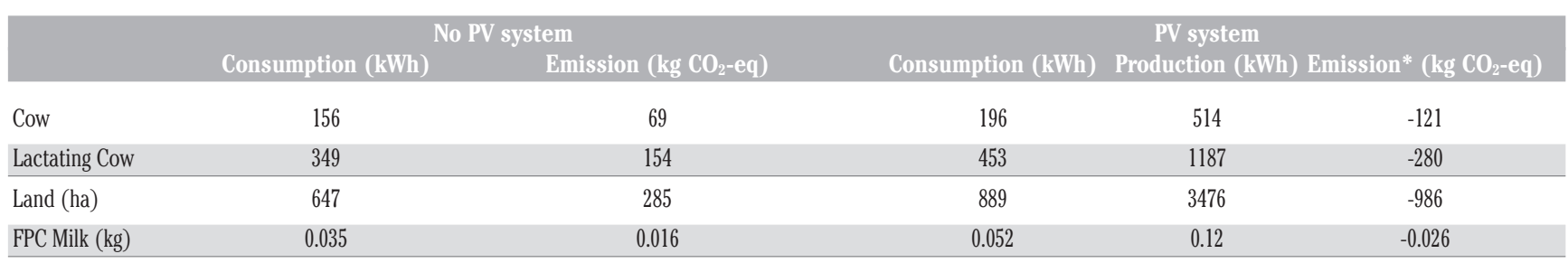

*Negative results indicate the avoided emissions due the surplus of PV energy produced 


\section{Conclusions}

Electricity and fuel consumption in dairy farms represent an important source of GHG emission into the environment. The present study determined the energy requirements for diesel and electricity at farm level, also underlining the critical point where mitigation strategies are needed. Additionally photovoltaic electricity generation was considered as a mitigation strategy to compensate the GHG impact of milk production. PV electricity can also help reducing the demand in dairy farms, especially decreasing the high peak of consumptions.

Electricity requests in the dairy farms involved in the study were mainly due to the operations regarding the milking parlour (milking, milk refrigeration and water heating), which required $50 \%$ of the total electricity consumption.

A large number of the investigated farms already use energy saving technologies, such as heat recovery system from cooling tanks ( $90 \%$ of farms), variable speed drive for the vacuum pump (60\%) and milk precoolers (30\%). Improving energy savings allow to reduce the electricity demand, especially for those equipments that need high electricity input. The estimated electricity emissions of $\mathrm{CO}_{2}$-eq were $78 \mathrm{~kg}$ per cow that correspond to $0.019 \mathrm{~kg} \mathrm{CO}_{2}$-eq per $\mathrm{kg}$ of FPCM.

Diesel consumption was assessed for land operations, feed management and slurry management and corresponds to $92 \mathrm{~kg}$ of diesel per cow and $392 \mathrm{~kg}$ per ha-1. The operations related to animal feeding, as crop cultivation, feed preparation and distribution, require the largest quota of total fuel consumption ( $42 \%$ and $52 \%$ respectively). The emissions associated to diesel combustion were $289 \mathrm{~kg} \mathrm{CO}_{2}$-eq per cow and $0.066 \mathrm{~kg} \mathrm{CO}$-eq per $\mathrm{kg}$ of FPCM.

Final results of carbon dioxide emissions from fuel and electricity usage showed that $79 \%$ of the emissions were due to the use of diesel. These results underline the need to focus the mitigation strategies in fuel usage, especially for feed management and land operations.

Reducing electricity and diesel consumption leads to decrease anthropogenic gas emissions into the environment, to reduce costs for the farms and to improve the efficient use of natural resources.

\section{References}

Crosson P., Shalloo L., O’Brien D., Lanigan G.J., Foley P.A., Boland T.M. 2011. A review of whole farm systems models of greenhouse gas emissions from beef and dairy cattle production systems. Animal Feed Science and Techology, 166-167:29-45

DeVries T. J., Vankova M., Veira D.M., Keyserlingk, 2007. Usage of
Mechanical Brushesby Lactating Dairy Cows. Journal of Dairy Science 90:2241-2245.

ENEA, 2010. Inventario annuale delle emissioni di gas serra su scala regionale, Le emissioni di anidride carbonica dal sistema energetico. Rapporto 2010.

Grisso R.D., Kocher M. F., Vaughan D.H. 2004. Predicting Tractor Fuel Consumption. Applied Engineering in Agriculture, 20(5):553-561

Institut de l'Elevage 2009. Les consommations d'energie en bâtiment d'elelevage laitier. Reperes de consommations et pistes d'economies. Collection : Synthese, Janvier

IPCC 2006. Guidelines for National Greenhouse Gas Inventories. Volume 4: Agriculture, Forestry and Other Land Use. Chapter 10: emissions from Livestock and Manure Management.

ISPRA 2011. Produzione termoelettrica ed emissioni di $\mathrm{CO}_{2}$. Fonti rinnovabili e impianti soggettia ETS. Rapporto 135/2011.

Jäkel K. 2003. Analyse der Elektroenergieanwendungund Einsparpotentialeam BeispielsächsischerMilchviehanlagen. Forschungsbericht Agrartechnik, 414, Mertin-Luther-Universitat Halle/Saale

Murgia L., Caria M., Pazzona A. 2008. Energy use and management in dairy farms. International Conference "Innovation technology empower safety, health and welfare in agriculture and agro-food systems", Ragusa, Italy, sept. 15-17, pp.1-7.

Raugei M., Frankl P. 2009. Life cycle impacts and costs of photovoltaic systems: Current state of the art and future outlooks. Energy 34 : 392-399

Rossi P., Gastaldo A. 2012. Consumi energetici in allevamenti bovini da latte. Informatore Agrario 3(Suppl):45-47.

Smith, P., D. Martino, Z. Cai, D. Gwary, H. Janzen, P. Kumar, B. McCarl, S. Ogle, F. 0'Mara, C. Rice, B. Scholes, 0. Sirotenko 2007. Agriculture. In "Climate Change 2007: Mitigation. Contribution of Working Group III to the Fourth Assessment Report of the Intergovernmental Panel on Climate Change" [B. Metz, 0.R. Davidson, P.R. Bosch, R. Dave, L.A. Meyer (eds)], Cambridge University Press, Cambridge, United Kingdom and New York, NY, USA.

Southern California Edison 2004. Dairy Farm Energy Management Guide California.

UNI EN ISO 14040, 2006. Environmental management, Life cycle assessment, Principles and frame work.

UNI EN ISO 14044, 2006. Environmental management, Life cycle assessment, Requirements and guideline.

West T. 0., Marland G. 2002. A synthesis of carbon sequestration, carbon emissions, and net carbon flux in agriculture: comparing tillage practices in the United States. Agriculture, Ecosystems and Environment, 91: 217-232. 